\title{
MIDWIFERY PRACTICE: \\ Core Topics 3
}

Edited by

Jo Alexander, Carolyn Roth

and Valerie Levy 
(c) Series Selection: Jo Alexander, Valerie Levy \& Sarah Roch 1990, 1993, 1995, 1996; Jo Alexander, Carolyn Roth \& Valerie Levy 1997, 2000

(c) This volume: Foreword, Cathy Warwick; Reflections on midwifery care and the postnatal period, Tricia Anderson and Jane Podkolinski; The need to talk after birth: evaluating new services, Sally Marchant and Jo Garcia; Perinatal grief: understanding the bereaved and their carers, Rosemary Mander; From pregnancy to lactation: changing relations between mother and baby - a biological perspective, Mary McNabb and Suzanne Colson; Breastfeeding update, Sally Inch; Sexual health in the postnatal period, Jill Stewart-Moore; Domestic violence and pregnancy: a midwifery issue, Chris Bewley and Andy Gibbs; Empowerment - a gift bestowed or withheld?, Gillian Fletcher and Elisabeth Buggins; Organisation of postnatal care and related issues, Debra Bick, 2000

All rights reserved. No reproduction, copy or transmission of this publication may be made without written permission.

No paragraph of this publication may be reproduced, copied or transmitted save with written permission or in accordance with the provisions of the Copyright, Designs and Patents Act 1988, or under the terms of any licence permitting limited copying issued by the Copyright Licensing Agency, 90 Tottenham Court Road, London W1P 0LP.

Any person who does any unauthorised act in relation to this publication may be liable to criminal prosecution and civil claims for damages.

The authors have asserted their right to be identified as the authors of this work in accordance with the Copyright, Designs and Patents Act 1988.

First published 2000 by

MACMILLAN PRESS LTD

Houndmills, Basingstoke, Hampshire RG21 6XS

and London

Companies and representatives

throughout the world

ISBN 978-0-333-76433-6 ISBN 978-1-349-15038-0 (eBook)

DOI 10.1007/978-1-349-15038-0

A catalogue record for this book is available

from the British Library.

This book is printed on paper suitable for recycling and made from fully managed and sustained forest sources.

$\begin{array}{llllllllll}10 & 9 & 8 & 7 & 6 & 5 & 4 & 3 & 2 & 1\end{array}$

$\begin{array}{llllllllll}09 & 08 & 07 & 06 & 05 & 04 & 03 & 02 & 01 & 00\end{array}$

Editing and origination by Aardvark Editorial, Mendham, Suffolk 


\section{Contents}

Other volumes in the Midwifery Practice series iv

Contributors to this volume $\quad \mathrm{v}$

Foreword viii

Preface $\quad$ xi

Acknowledgements xiii

1. Tricia Anderson and Jane Podkolinski: Reflections on midwifery care and the postnatal period 1

2. Sally Marchant and Jo Garcia: The need to talk after birth: evaluating new services

3. Rosemary Mander: Perinatal grief: understanding the bereaved and their carers

4. Mary McNabb and Suzanne Colson: From pregnancy to lactation: changing relations between mother and baby - a biological perspective

5. Sally Inch: Breastfeeding update 66

6. Jill Stewart-Moore: Sexual health in the postnatal period 83

7. Chris Bewley and Andy Gibbs: Domestic violence and pregnancy: a midwifery issue

8. Gillian Fletcher and Elisabeth Buggins: Empowerment a gift bestowed or withheld?

9. Debra Bick: Organisation of postnatal care and related issues 


\section{Other volumes in the Midwifery Practice series}

- Midwifery practice: Core topics 1 ISBN 0-333-66320-9

Rosemary Currell: The organisation of maternity care

Greta Curtis: Preconception care

Jennifer Wilson: Antenatal risk assessment

Colin Rees: Antenatal education, health promotion and the midwife

Elsa Montgomery: Fetal wellbeing: the intrauterine environment and ensuing legal and clinical issues

Jane Denton: Pregnancy after treatment for infertility

Helen R. Minns: Women with learning disabilities: the midwife's role Tansy M. Cheston: Pre-eclampsia

Kathleen King: Marketing midwifery services

Midwifery practice: Core topics 2 ISBN 0-333-69627-1

Rona Campbell: Place of birth reconsidered

Carole Yearley: Motherhood as a rite of passage: an anthropological perspective

Chris Bewley and Cliff Roberts: Injectable methods of pain relief in labour

Sue McDonald: Active management of labour

Maxine Wallis-Redworth: Emergencies during labour: umbilical cord prolapse and inversion of the uterus

Tansy M. Cheston: Diabetes mellitus in pregnancy

Rona McCandlish: Care during the second stage of labour

Juliet Wood and Jane Rogers: The third stage of labour

Carol Bates: Care in normal labour: a feminist perspective

\section{- Aspects of midwifery practice ISBN 0-333-61956-0}

Sally Spedding, Joan Wilson, Sarah Wright and Alan Jackson: Nutrition for pregnancy and lactation

Rosaline Steele: Midwifery care in the first stage of labour

Elaine Carty: Disability, pregnancy and parenting

Terri Coates: Shoulder dystocia

Catherine Siney: Drug addicted mothers

Carolyn Roth: HIV and pregnancy

Jennifer Sleep: Postnatal perineal care revisited

Susan L. Smith: Neonatal hypoglycaemia

Sally Marchant and Jo Garcia: Routine clinical care in the immediate postnatal period 


\section{Contributors to this volume}

Tricia Anderson BA (Hons), MSc, RM

Lecturer in Midwifery/Independent Midwife, Institute of Health and Community Studies, Bournemouth University

Tricia Anderson trained as a midwife in Dorset, where she worked in both hospital and community settings before commencing independent practice in 1997. She was formerly Editor of the MIDIRS Midwifery Digest and Coeditor of the Informed Choice Initiative. She is now Associate Editor of Practising Midwife and part-time lecturer in midwifery studies.

Chris Bewley MSc, BEd, RN, RM, ADM

Senior Lecturer in Midwifery, Middlesex University

Chris Bewley has 10 years' experience of writing and speaking on the subject of domestic violence and pregnancy. She has also written about interpersonal and educational issues relating to midwifery and cocontributed a chapter on 'Injectable methods of pain relief' to the previous volume in this series.

Debra Bick BA, MMedSci, RGN, RM

Research Fellow in Midwifery, University of Birmingham

Debra Bick's main research interests concern aspects of maternal health after childbirth. She is currently involved with two large randomised controlled trials, the results of which will inform evidence-based care for women during labour and the puerperium.

Elisabeth Buggins MHSM, DipHSM

Chairman Walsall Community Health NHS Trust

Elisabeth Buggins has a wide experience of involvement with both the NHS and the voluntary sector. Now Chairman of Walsall Community Health NHS Trust, and of Wolverhampton MSLC, she aims to build strong, multidisciplinary, multiagency teams that work constructively to effect change.

Suzanne Colson RGN RM BA Licence ès Lettres (France)

Rosie Maternity Hospital, Cambridge

Suzanne Colson is clinical facilitator for research and development in transitional care. For her MSc thesis, she is examining aspects of suckling ketosis. She has worked as baby feeding advisor at Pithiviers Hospital, France and the Royal Free Hospital, London where she was seconded to UCH to complete breastfeeding research concerning metabolic adaptation in the preterm infant. 
Gillian Fletcher MCSP, NCT Antenatal Tutor

Freelance Trainer

Gillian Fletcher has been involved in antenatal and postnatal work for 27 years and was responsible for setting up the NCT teacher training programme in Europe. With a physiotherapist colleague, she developed the NCT postnatal exercise training programme. Gillian is author of Get Into Shape After Childbirth, and is currently working on a user involvement project with the College of Health.

Jo Garcia BA, MSc

Social Scientist, National Perinatal Epidemiology Unit, Oxford

Jo Garcia is currently Director of the Midwifery Research Programme at the NPEU. She has written widely and has contributed, with Sally Marchant, to a previous volume in the series.

\section{Andy Gibbs}

Head of Department of Child Health, Mental Health and Learning Disabilities, Napier University, Edinburgh

Andy Gibbs is also Research Fellow for the National Board for Nursing, Midwifery and Health Visiting for Scotland and is currently researching midwives' experiences of interventions with regard to domestic abuse.

Sally Inch RM, RN

Breastfeeding Advisor and Baby Friendly Co-ordinator for the Women's Centre, Jobn Radcliffe Hospital, Oxford

As well as her two books on aspects of birth, Birthrights and Approaching Birth, Sally Inch has written widely on the subject of breastfeeding, coauthoring, editing and contributing to numerous books, papers, articles and videos. Since May 1998, she has worked with Chloe Fisher in the Oxford Breastfeeding Clinic.

Mary McNabb MSc, BA, RN, RM, ADM, PGCEA

Senior Lecturer, South Bank University

Mary $\mathrm{McNabb}$ has a longstanding interest in reproductive biology and social ecology. She has written the biology chapters for the current edition of Mayes' Midwifery and is currently working on a chapter on embryo formation and fetal development, for a forthcoming physiologically based textbook on child health.

Rosemary Mander MSc, PhD, RGN, SCM, MTD

Reader, Department of Nursing Studies, University of Edinburgh

Rosemary Mander is involved with teaching at postgraduate level, as well as undertaking research. She has an honorary appointment that facilitates her practice as a midwife at a local maternity unit. Her activities in the university and in the maternity unit both serve to inform her writing on midwiferyrelated topics. 
Sally Marchant RN, RM, ADM, Diploma in Research Methods Research Midwife, National Perinatal Epidemiology Unit, Oxford

Sally Marchant's main interest is in women's health following childbirth, particularly in the ways in which midwifery care can help to reduce women's morbidity, both physical and psychological, during the postnatal period.

Jane Podkolinski BA (Econ), MSc, SRN, SCM, DPSM

Practising Midwife

Jane Podkolinski has a first degree in economics. She then began to train as an accountant, but in 1975 changed direction to pursue a career in nursing. She qualified as a midwife in 1979 and has been working since then in all aspects of clinical midwifery in both hospital and community settings.

Jill Stewart-Moore RN, RM, MTD, MSc Chair of the Management Committee of Belfast Brook Advisory Centre Jill Stewart-Moore has experience of family planning, nursing and midwifery lecturing in South London and now Belfast. 


\section{Foreword}

As a midwife, the provision of postnatal care has always fascinated me. Many commonly held beliefs about this important period in women's lives have never quite made sense. Could it really be unsafe for a mother to cuddle her baby in bed with her? Were small four-bedded bays automatically a superior hospital design in which to care for women? Why was it considered that women having their first baby would fare better staying in hospital longer than women having their second or third baby? The complete opposite of what was common practice often seemed far more logical. As a community midwife, I solemnly carried out the ritual physical examination of mother and baby but, at an early stage in my career, I doubted that it was the examinations in themselves that were of most importance. Was it not something about the interaction they necessitated between the mother and the midwife?

Now, as a midwifery manager, I can see clearly that one of our greatest challenges as a profession is to try to understand what it is about the postnatal period that matters to women and how the care we give can best enable women to fulfil their role as mothers. As Tricia Anderson and Jane Podkolinski point out in the book's introductory chapter, postnatal care throughout the country is poorly evaluated. Surveys of user opinion suggest that midwives struggle to perform a set of rituals of unproven value while failing to provide the support women really want or need. Community midwives have adopted patterns of selective visiting with the overt aim of tailoring care more specifically to the needs of women, but it is hard not to be cynical and imagine that the tailoring has something to do with the workload and pressures experienced by the midwives.

It would be wrong to be too negative, and that is quite rightly not the tone of the book. Care provision has changed and, all over the country, patterns of care based on available evidence are developing. Furthermore, the authors of this book, in their presentation of the theoretical basis for care and of the evidence, frequently support the fact that certain current practices are both justifiable and useful. This will very importantly build the confidence of practitioners. I do quite deliberately use the term 'practitioners'. The book is not directed at one professional group. In fact, many authors specifically mention the need for a multidisciplinary approach, and midwives, GPs, health visitors, paediatricians and obstetricians could all benefit from the insights and ideas contained in the various chapters. 
I hope that the greatest contribution of this book will be to help professionals to look at postnatal care differently and to consider how their practice might alter. The book specifically attempts to promote change through its style of concluding each chapter with a section encouraging professionals to consider their own practice or their own service in the light of what they have read. This is a very welcome step. Theories and ideas are all very well, but it is widely understood that they do not in themselves ensure that care improves.

Important themes recur throughout the book. Two of these are the need to treat women as individuals and the need to ask the users of the services what matters to them. It may be surprising that such issues still need emphasis, but, in my experience, the focus on providing individualised and women-centred care has concentrated on the antenatal and labour periods. Furthermore, this is about getting things right not just for individual women but for all women - it is about changing policy and the content of care, not just about doing the same things differently.

Of course, radical change is unsettling. If the old rituals of postnatal care are invalid, what do professionals do? The beauty of the book is that it offers positive ways forward. Women need to talk (Chapter 2); domestic violence presents a major challenge (Chapter 7); promoting women's sexual health can avoid much unhappiness and morbidity (Chapter 6). Professionals should adopt a much broader perspective than in the past.

Research is emphasised throughout the book. The various authors present research evidence to counteract widely held beliefs and myths and to suggest alternative ways in which professionals might practise. There is, however, a real danger in slipping from one set of discredited practices into a new set of unproven rituals. Very importantly, authors, particularly Sally Marchant and Jo Garcia, emphasise the need to evaluate new practices. It is encouraging, particularly in Debra Bick's chapter, to see that large-scale research projects into the organisation of postnatal care have recently been funded.

Although the issue of ethics is not specifically addressed, it is interesting to note how frequently the question emerges of whether or not care is ethical. In her chapter on breastfeeding, Sally Inch argues that it would be both patronising and dishonest to withhold the facts about the benefits of breastfeeding to protect the woman from 'feeling guilty'. Chris Bewley raises a rather different point when, in discussing the importance of screening for domestic violence, she points out that it 'would be unethical to encourage disclosure in the absence of a sound supportive infrastructure and system for referral'. It is issues like these that highlight for me that this is an important book which must be read by policy-makers as well as practitioners if we are to achieve optimum care.

It is important to point out, however, that even where a practice is considered 'right', the authors do not imply that this justifies its automatic imposition on women. Sally Inch goes on to say that having ascertained 
that the mother has made an informed choice, health professionals have a duty to support the mother in her choice and assist her to bottle feed safely'. It is this emphasis on getting care right for individuals that emerges again and again.

Perhaps what strikes me most in reading this book is that providing postnatal care is not straightforward. The story that illustrates this most profoundly is the tale of how human milk banks were closed in the late 1980s because of a fear of HIV transmission. This was despite evidence of the effectiveness of pasteurisation in destroying the virus and just before there was overwhelming evidence that there was an increased risk of necrotising enterocolitis in preterm infants who were excessively formula fed. It is easy to criticise professionals for getting it wrong, but perhaps what is most surprising is how often they manage to negotiate all the hurdles and give a good service. It is apt that a final theme of this book, which is particularly emphasised in Gillian Fletcher and Elisabeth Buggins' chapter on empowerment, is that if professionals are to help mothers, they themselves will need support and appropriate education.

This is a book in which the authors examine the art and science of postnatal care. It will, I hope, make a valuable contribution as we continuously strive to provide a service of excellence. It is, I contend, impossible to read this book and not reflect on how one's current practice might change for the better.

Catby Warwick KINGS NHS TRUST 


\section{Preface}

The planning of this book, the eighth volume in the Midwifery Practice series, coincided with the publication of the Audit Commission report First class delivery (1997) which revealed that women are more critical about hospital postnatal services than about any other aspect of their maternity care. The report highlighted the considerable variation that exists in the way in which postnatal care is organised and the level to which it is resourced; it stressed the need for clear objectives, quality standards and genuine partnership with women.

The issues raised in the report have important implications for midwives as the reappraisal of the needs of women, babies and families in the postnatal period demands a critical assessment of the knowledge, skills and perspectives of midwives giving postnatal care. In our opinion, postnatal care has a vital role to play in promoting health in its broadest sense, and we hope that what follows will make a contribution to the important debate on what that care should include.

Throughout this series, our intention as editors has been to encourage midwives' access to sound, well-referenced material that addresses issues arising within their clinical practice. The series has developed alongside the increasing access to and use by midwives of tools such as the Cochrane Library and the MIRIAD Midwifery Research Database, as well as a proliferation of critical discussion on midwifery knowledge and practice, reflected in the growing number of research-based midwifery journals. We believe this series provides an additional resource for the benefit both of those with a limited opportunity for inquiry and those wishing to investigate topics further.

We are grateful for the work of all our contributors. They have critically appraised a wide range of literature and evidence of relevance to midwifery practice. The collection will, we hope, stimulate readers' consideration of a range of research approaches and sources of knowledge that can enhance their understanding of midwifery practice and the challenges it presents. We believe that the current edition continues our objective to strengthen the dynamic links between education, practice and research.

Finally we would like to thank our publishers, especially our outstanding publishers' editor, Richenda Milton-Thompson, and Carrie Walker our copy-editor. 


\section{Common structure of the chapters}

In fulfilment of the aims of the series, each chapter follows a common structure:

1. The introduction offers a digest of the contents;

2. 'It is assumed that you are already aware of the following...' establishes the prerequisite knowledge and experience assumed of the reader;

3. The main body of the chapter then reviews and analyses the most appropriate and important research literature currently available;

4. The 'Recommendations for clinical practice' offer suggestions for sound clinical practice, based on the author's interpretation of the literature;

5. The 'Practice check' enables professionals to examine their own practice and the principles and policies influencing their work;

6. Bibliographic sources are covered under 'References' and 'Suggested further reading'.

\section{- Reference}

Audit Commission (1997) First class delivery: improving maternity services in England and Wales. Audit Commission, London

\section{- Suggested further reading on research}

Couchman W, Dawson J (1995) Nursing and Healthcare Research, 2nd edn. Scutari Press, London.

Distance Learning Centre modules (1987-95) Research Awareness: A Programme for Nurses, Midwives and Health Visitors, Units 1-11. South Bank University, London.

Hicks C (1990) Research and Statistics: A Practical Introduction for Nurses. Prentice Hall, Hemel Hempstead.

Parahoo K (1997) Nursing Research: Principles, Process, Issues. Macmillan, Basingstoke.

Polit DF, Hungler BP (1995) Nursing Research: Principles and Methods, 5th edn. JB Lippincott, Philadelphia.

Robson C (1993) Real World Research: A Resource For Social Scientists and Practitioner-researchers. Blackwell, Oxford. 


\section{Acknowledgements}

Every effort has been made to trace all copyright holders, but if any have been inadvertently overlooked, the publishers will be pleased to make the necessary arrangements at the first opportunity. 